\title{
Conventional Banks Risk Diversification: A Case for Islamic Finance
}

\author{
Issam Tlemsani ${ }^{*}$, Robin Matthews ${ }^{2}$ \\ ${ }^{1}$ IE Business School, Calle de María de Molina, Madrid, Spain \\ ${ }^{2}$ Kingston Business School, London, UK \\ Email: ^i.tlemsani@tcib.org.uk, R.Matthews@kingston.ac.uk
}

How to cite this paper: Tlemsani, I. and Matthews, R. (2019) Conventional Banks Risk Diversification: A Case for Islamic Finance. Theoretical Economics Letters, 9, 1967-1980.

https://doi.org/10.4236/tel.2019.96125

Received: July 12, 2019

Accepted: August 24, 2019

Published: August 27, 2019

Copyright (c) 2019 by author(s) and Scientific Research Publishing Inc. This work is licensed under the Creative Commons Attribution International License (CC BY 4.0).

http://creativecommons.org/licenses/by/4.0/

(c) (i) Open Access

\begin{abstract}
This paper challenges the idea that the conventional financial sector either innovates or diversifies risk. To understand diversification of risk and the true nature of innovation in finance, this paper distinguishes between risk spreading and risk sharing. Risk spreading characterises conventional finance and risk sharing characterises Islamic finance. We argue that the case for Islamic type financing in the sense of risk sharing is a safer approach and overwhelming for governments, regulators and for financial institutions that consider themselves innovators in an historic sense, contributors to society rather than greedy acquisitors of personal wealth. Effectively, innovation according to the originate and distribution model of banking amounts to (a) a wealth transfer from the rest of the world to people in financial sectors, mostly in developed economies and/or (b) asset depreciation/default. We are describing a situation rather like that described by the story told to children about the emperor having no clothes. In the story, an emperor, suffering from an excess of pride or insecurity, is manipulated by an exploitive tailor into believing he has been supplied with magnificent robes that only the privileged and enlightened can see. No one dares to believe their own eyes that tell them unequivocally that the emperor is naked, except a child, who blurts out: "why is the emperor naked?" Why is there not a similar response to the nakedness of the financial sector, when its contribution, nationally and internationally has been so massively negative? We argue that one of the reasons is that we, meaning governments, regulators, bankers and the rest of us, are mostly divided into three groups; those who understand the mathematics of finance but not financial institutions, those who understand financial institutions but not the mathematics of finance and those who understand neither. The purpose of this paper is to examine conventional finance risk diversification and compare it to the Islamic finance risk sharing approach. The findings of this paper demonstrate that the Islamic finance risk sharing approach is safer.
\end{abstract}




\section{Keywords}

Financial Risk, Crisis, Islamic Finance, Financial Stability

\section{Introduction}

Undoubtedly, the growth of national financial sectors has been critical to national economic growth historically. [1] found "a positive, significant, and correlation between the average annual rate of real per capita GDP growth and the average level of financial sector development", but globalisation and the rise of the originate and distribute model of banking have changed the role of financial sectors entirely. Beyond a certain critical size, the contribution of financial sectors to society becomes like that of a public good [2]. Their contribution depends on their existence rather than their size (in asset or income values) but beyond a certain critical size, conventional financial sectors become dysfunctional and make a negative contribution he estimates of the cost of 2008 financial crisis range somewhere between $\$ 60$ trillion and $\$ 200$ trillion [3] [4].

Criticality can be measured and predicted by 1 ) the size of financial sectors relative to the size of national economies i.e. in 2013 the financial sector contributed $20 \%$ to US GDP, $8.3 \%$ in 2006, 4.9\% in 1980 and $2.8 \%$ in 1950 and 2) the degree of interdependence between financial sectors internationally. That critical point has been reached and exceeded, making the next financial crisis originating in conventional financial sectors inevitable. Yet governments have backed away from measures that would alleviate the problem. We are faced with massive ignorance about what a financial sector actually does, both by those outside and inside financial sectors.

Once the financial sectors have gone beyond a critical size, banks don't really innovate or spread risks. Beyond that point, innovation means expanding the range of securities, mainly debt: leveraging financial assets against other financial assets. It is argued that diversified portfolios spread risk, beyond the critical point they don't. If everyone holds the perfectly diversified portfolio; the portfolio that corresponds to the market portfolio, when the market fails, everyone fails, and once we incorporate feedbacks into financial networks it is inevitable that when one part of an innovative financial system (equivalently a heavily leveraged financial system) fails, the entire (global) financial system fails and failure percolates throughout other sectors in the global economy. Risk is a public good. One institution's diversification of risk does not reduce risk; it merely spreads it more widely and disastrously.

The discourses of Islamic and conventional finance differ. According to the principles of Islamic finance, there is no separation of the spiritual and the secular. Islamic finance is explicitly concerned with spiritual values and social justice, in contrast to conventional finance, which is based on the maximisation of individual utility, welfare and choice, as expressed for example in the shareholder value model. A fundamental principle of Islamic finance is the prohibition of 
riba (usury). The most prevalent method of risk management is risk sharing by Mudaraba or Musharaka profit and loss sharing, compensation to lenders is in accord with an agreed ratio of the profit/loss outcome of an investment project. The discourse of Islam involves: 1) equity rather than debt, 2) financing in strict relation to tangible assets rather than leverage, 3) transparency and information sharing between investor and the manager, 4) diversification of risk by risk sharing. In contrast, the discourse of conventional finance failed due to: 1) excess debt, 2) overleveraging of assets, 3) excessive securitization and creation of new assets that were neither transparent nor understood and 4) diversification of risk, based on unreal models, all leading to massive systemic risk, the too big to fail problem and the need for bailouts.

The principles of Islamic finance differentiate it from conventional finance and thus it would seem likely to be removed from the corresponding crises of conventional finance. In reality, this is not the case ${ }^{1}$ [5]. As globalisation prevails financial institutions, economies are increasingly interdependent, preventing the de-coupling of the Islamic and conventional finance systems. Additionally, recession effects growth, employment, trade and equities. Islamic finance can only be insulated if institutions under conventional finance adopt a regulatory system that insists effectively on: 1) increasing the asset base of banks; 2) reducing leverage; 3 ) relating it to investment risk and 4) greater transparency. These measures will align the two discourses, moving conventional finance closer to the principles of Islam. In a sense these requirements are merely cosmetic and we are not confident that a sufficient degree of co-operation exists for supervisory change. The debate regarding traditional finance has been a priority among regulators, researcher/academics, politician and practitioner in order to try and avoid the next financial crisis. A more central necessity for real improvement to the financial industry is to rebuild the current separation between spiritual and the secular, reducing the weight of the corporate profit maximisation and increasing the focus on social justice.

This paper is structured as follows: Section (I) is a background to the subject and provides the purpose of this paper which is examining the conventional versus the Islamic banks risk diversification. Section (II) provides an overview of the financial crisis narrative. Section (III) outlines how the ideology of the conventional discourse of finance has changed in practice and compares it to Islamic economic thoughts. Section (IV) illustrates some differences between Islamic and conventional finance in terms of risk sharing instruments using a comparison approach between conventional and Islamic mortgages. Section (V) contains the discussion and conclusions.

\section{Financial Crisis Narrative}

Over the last 30 years, governments in mature economies have placed excessive

${ }^{1}$ Nakheel, owned by Dubai World, restructured its $\$ 980$ million Sukuk. Investment Dar, the Kuwaiti Islamic investment firm, defaulted on its $\$ 100$ million Sukuk and Nakheel, the real-estate subsidiary of Dubai World, was bailed out by Abu Dhabi on its $\$ 3.5$ billion Sukuk. 
emphasis on maximization of corporate profit and attachment to material wants. More and yet more emphasis on consumer choice and consumption have become primary goals. This has led to living beyond means in the public, household and government sectors. Consequently, there has been a phenomenal rise in debt, US debt in February 2019 exceeded \$22 trillion with debt to GDP 104\%. Even the United States, the richest country in the world, has become the most indebted (currently in a deficit crisis).

The current phase of globalisation emerged from positive feedbacks in final 25 years of the twentieth century between finance, deregulated finance, technology and globalization [6]. In 2004 the securities and exchange commission (SEC) permitted investment banks to increase their leverage from 10 to 1 to 30 to 1 shortly before its collapse, leverage at Lehman Brothers was at 44 to 1 with $\$ 748$ billion in assets standing atop $\$ 17$ billion in equity [7]. Citigroup 56 to 1, Bank of America 38 to 1 and GE 54 to 1 . Funded technology and innovation (since 1980's financial institutions have engaged in a massive effort to hire $\mathrm{PhD}$ graduates in physics, engineering, business analytics and mathematics to create increasingly complex and highly lucrative new financial instruments) has resulted in increased output, productivity and shorter product cycles. Firms needed global demand to absorb their increased output and global finance to fund innovation and the purchasing power plus cheap labour, supplied globally, to be cost-competitive.

\section{Chicago versus Islamic Economics}

In this section, we begin by comparing two discourses and then outline how the ideology of the conventional discourse of finance has changed in practice, although policymakers are largely in denial of the change. [8] divides the history of the Chicago School into 3 periods. The Chicago approach to economics is extraordinarily coherent and that is the root of both its attraction and its deception. Brilliant extensions of Alfred Marshall's economics are contained in [9] [10]. The arguments of both of these texts are hedged by careful assumptions that rarely apply completely to actual situations, but these assumptions are too easily passed over by MBA students looking for facile, unambiguous solutions to complex problems.

\subsection{Comparisons}

Although the latest crisis appears to originate in the financial sector, the origins are much deeper. Capitalism and the relentless search for competitive advantage, has resulted in huge volumes and variety of goods and services. Demand has to keep pace with supply, which marketers seem to understand, but economists have ignored. Over the last twenty years, the manic search by firms for competitive advantage has been most marked in the speculative mentality of the financial sector, creating towers of debt based on speculation. At the most general level, the contrasting feature of the discourses is that what we have classified as 
Chicago economics is essentially anthropomorphic, people-centered: whilst the tenet, central to Islam, is that God is the Creator and ultimate Owner of wealth, and people are vicegerents, who should use the gift of wealth, only as His trustees [11].

Globally there is both a liquidity crisis (a credit crunch or what Keynes called a liquidity trap) and more seriously an insolvency crisis. Many of the assumptions or conventional wisdom about business and economics, treated over the last 25 years as self-evident truths have been falsified, but obstinately remain dominant in the discourse.

The main propositions of the Chicago School that have been so influential since the 1950's are described in Table 1, proposition markets for goods, services, and factors of production are said to be efficient in that they maximise all possible benefits from trade and free exchange (Pareto optimality). Stock markets are efficient in that stock prices incorporate all relevant information (information efficiency) about a firm, so that stock prices follow a random walk. Propositions 2 and 3 follow from 1 and lead to the textbook supply and demand that if prices (including wages and interest rates) are flexible there should be full employment. In fact, markets are not efficient informationally and often lead to persistent unemployment. Proposition 4 follows from the judgement that the role of firms is to maximise shareholder value. Proposition 5 is embedded in supply-side explanations of economic growth. Proposition 6, decision theory based on rational expectations assumes that 1 ) individuals, acting rationally, use all the information they have to maximise their utility and 2) that everyone has access to the same information. In fact, 1) irrationality is apparent in markets everywhere: in mortgages, in securitisation, derivatives and banking generally (even self-styled wizards, behave stupidly) and 2) individuals had access to different information.

Proposition 6, the role of governments, via the central bank, should be limited to keeping money supply growth in line with real growth of the economy this is

Table 1. Falsified Chicago propositions.
1) that markets are efficient
2) that capitalism can be deregulated effectively
3) that government intervention is inefficient
4) that the goal of firms is to seek competitive advantage
5) that it is supply rather than demand that matters
6) that reliance on monetary policy can cure depressions
7) that the probability of extreme events can be ignored
8) that aggregate risk can be diversified away
9) that the financial sector creates wealth
10) that the concern of globalization should be growth not distribution
11) that world growth rates years are sustainable indefinitely 
the classic statement by [12]. The credit crunch is a liquidity trap in which monetary policy does not work. Increases in the money supply, (quantitative easing) are either hoarded or lent at usurious rates; stimulating erratic asset price fluctuations.

Proposition 7 more or less rules out extreme events in financial markets: 1) by assuming that, in aggregate, financial market prices follow a normal (Gaussian) distribution, with limited variance, 2) constructing the price of complex assets on models that used too little data, and 3) relying on recent data that reflected (in an upswing of the cycle) that usually reflected rising prices. [13] [14] identify financial markets with fat-tailed distributions that accept that extreme events occur with great frequency. [15] draws on secondary data and finds 117 systemic banking crises in 93 countries between 1970 and 2003: 27 of them raising public debt by more than $10 \%$ of debt to GDP. [14] [16] both agree that large amounts of data are necessary to obtain the face of extreme events, much larger than is usually the case. In a fat-tailed distribution the tail come to zero bit by bit than exponentially; $\operatorname{Pr}[X>x] ; x^{-(1+\alpha)}, x \rightarrow \infty, \alpha>0$ for a thin tail distribution $\alpha=0$.

Contrary to proposition 8 , the recent financial crisis reveals that neither financial nor market risks are a private good but are public, since all market players are exposed to systematic risk which is uncontrollable and impacts large markets, thus it cannot be reduced through diversification (it is an insurable risk). Bailouts are eventually financed out of taxes consequentially government deficits increase although this can be recovered through raising taxes, spending cuts, borrowing money and subsequent interest rate increases.

On Proposition 9, value created by the financial sector has, in our view, been vastly exaggerated by its own discourse. Basic roles are to redistribute savings and consumption over time, channel investment to high return uses, hedge risk and organize liquidity. Apart from these functions, it operates as a casino, making the notion of market efficiency rather ridiculous. Remuneration systems in banks provide incentives to take too much risk, and obscure reflection on flaws in their models. Poor regulation and greed explain the abusive lending practices that were so large a part of this crisis, of past crises and will be a large part of future crises see [15] [17] [18] [19] chart the long history of repetitive financial crises.

Propositions 10 and 11 recall the contrast between the discourse of conventional finance which separates the secular and the spiritual and the principles of Islamic finance, one of whose purposes is to moderate differences in income, wealth and may pursue wealth but as trustees of God [11].

Our comments are reflections on the pragmatism of the Islamic finance principles, that of itself, money, without appropriate effort, does not create wealth. Instead of "no risk, no gain" there is gain only if prepared to share the risk. Markets are central to Islam, but one role of the Islamic state, is that of protection, which includes necessary regulation. Ethical behaviour is a requirement of 
secular or business activity. [11] requires obedience to God, his Prophet and their rules contradicting the anthropo-centrism of Chicago economics.

The effect of liquidity traps on interest rate (IR) has another dimension. With conventional finance in the west, as excess stock and unemployment rise, asset deflation occurs. While central banks may reduce federal base rates, the real (IR) will still increase as the (IR) is the nominal rate minus inflation. Liquidity thus does not reach businesses as financial institutions are to share the business risk, banks are averse to business risk and quantitative easing promised by Ponzi financing increases the price of financial assets, debt and equities. Thus, the global crisis worsens as debt increases, real (IR) increases and the burden of debt upsurges.

\subsection{Risk and the Shadow of Default}

One of the misconceptions of conventional finance is that risk, in the aggregate, can be diversified away. On the contrary risk, in aggregate, cannot be reduced. It can only be shared. Modern financial institutions are interdependent and this has always been the case, but in the global economy and as a result of the original and distributed model, it is even more prevalent. All risk is systemic, and a public good arising from the nature of time and uncertainty (as opposed to a private good) is non-excludable and non-rival, non excludable because everyone is affected by it; non rival because one person's experience of it does not reduce the experience of others. Hence risk can only be diversified or shared, not reduced.

\section{Conventional and Islamic Finance Demonstrate}

Figure 1, illustrate some dissimilarities among Islamic and conventional finance.

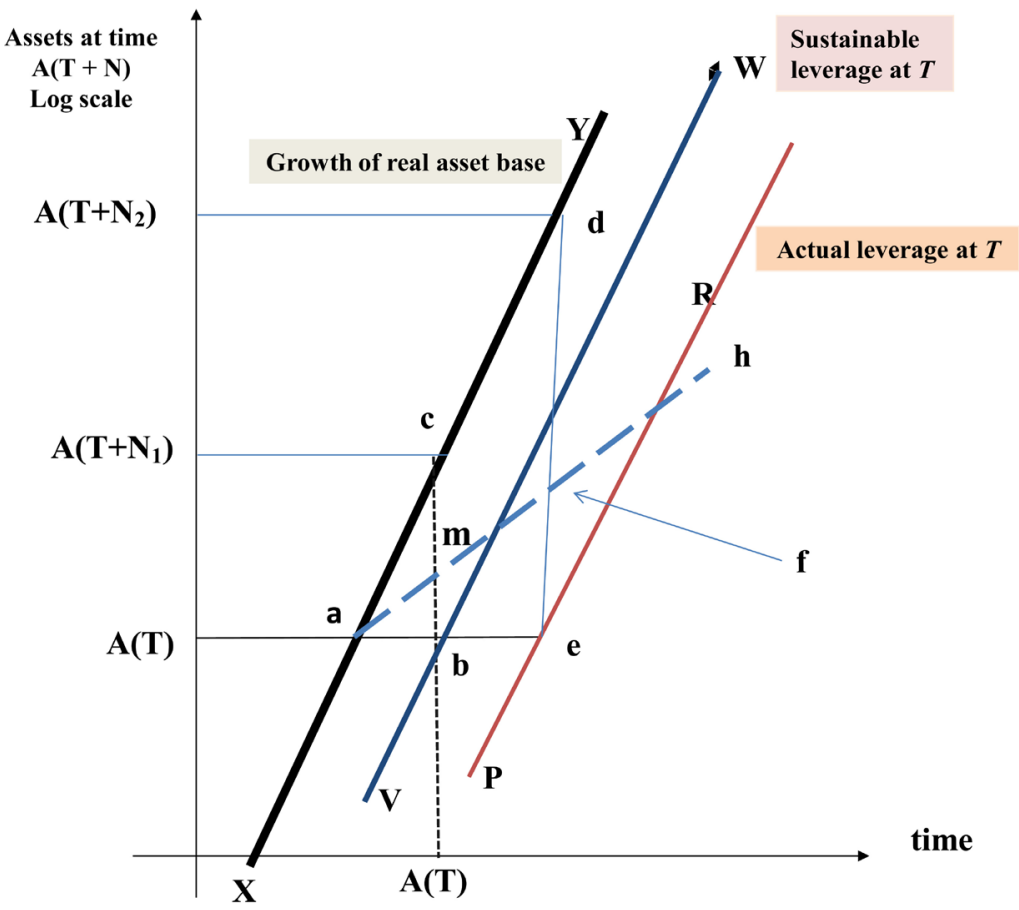

Figure 1. Assets at time $T \log$ scale. 
It is an aggregate picture, measured on log scales. In the diagram, the horizontal axis shows the value of assets currently $A(T)$, the vertical axis shows their value in a growing economy at some time in the future $A(T+N)$, given an exponential rate of sustainable growth $K$, represented by the slope of the line $X Y \log A(T+N)=\log A_{0}+K \log A(T)$ we presume the increase of $K$ is a long term average through a stochastic component that amounts to zero over time.

At time $T$, sustainable leverage achieves sustainable growth given by $X Z$. The sustainable leverage, $a b$ in Figure 1 is a multiple of the tangible asset base and is determined by attitude to risk. The tangible asset base is defined to include both human and physical capital and is taken to be measured by the horizontal axis, by the line segment $A(T) \leftrightarrow a$. We call capabilities collectively, $A$. The sustainable leverage $a b$ results in asset growth $b c$, in the time interval $T \leftrightarrow T+N_{1}$. This sustainable leverage is generally a multiple of the tangible asset base: in Islamic finance this depends on the value of enterprise. If we assume that sustainable leverage is a constant proportion of assets, in value terms, it will increase as assets grow, but at the current asset value, it will pass through a 45-degree line from the origin. The 45-degree, with assets $A(T)$ line is omitted in the diagram. In a non-Islamic setting sustainable leverage should be no different (but we qualify this in a moment).

Assuming that growth is not a stochastic event, normally distributed, with limited variance over a trend rate $\mathrm{K}$ but instead assume events in financial markets are fat-tailed, with crisis events being frequent features; it seems that we do not learn from former crises as seen in [15] [17] [18] [19]. If we assume crises have a long term impact, the sustainable growth line's slope will slow to $K^{*}$ permanently $\left(K^{*}<K\right)$. Then we have an insolvency crisis, measured by $f d$, an asset deficiency in the face of the leverage ae. A balance sheet depression occurs as businesses try to deleverage and thus the previously mentioned sequence of events follows.

\subsection{Islamic Finance Risk/Reward Sharing}

Risk/reward sharing instruments are largely similar to conventional private equity, venture capital and direct investment type investments in which the investor takes a business risk in the enterprise. In return for taking a risk, the investor shares in the profits, but is also exposed to losses in the event the enterprise is unsuccessful. Islamic finance replaces interest-based transactions by return-based transactions contracts, often in the form of partnerships. Here, profits are shared on a predetermined basis between investors and the bank. This risk and reward sharing implies that the profitability of the physical investment is of significance for the Islamic bank, that is the creditor. In the next section, we compare the Islamic with the conventional mortgage.

\subsection{Conventional Mortgage}

Let's assume a home loan of $£ 100 \mathrm{k}$ with 30 years mortgage a $10 \%$ deposit, an 


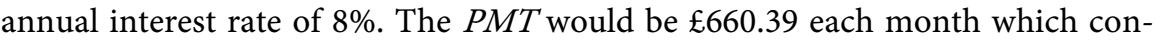
sist of principal and interest. The total payment of $£ 237,740$ paid to the bank includes $£ 147,740$ interest payment. Table 2 below illustrates the summary of the home loan.

\subsection{Islamic Ijara (Leasing) Mortgages}

The distinguishing features of an Ijara mortgage are risk sharing and joint ownership of the property in question from the outset. For example, under the Ijara based mortgage if the client (the borrower) contributes $10 \%$ of purchase price and the Islamic bank the remaining $90 \%$ the client thus has a $10 \%$ stake in the property and the bank 90\% (Diagram 1).

\subsection{Ijara Based Mortgage Mathematic Model}

We will highlight the different features of Ijara mortgage by developing a mathematic model. $X(t)$ is the client shares in the property at time $(t)$, and the changes in shares is $\Delta X(t)$

The clients' payments as a proportion of the original price plus the change in the house price are written as $S(t)$

$S(t)=\frac{\text { Client's initial deposit at } t_{0}+\text { Total rent payemnts from } t_{0}}{\text { Purchase property price }+ \text { fees }+(\text { Present house price }- \text { Purchase property price })}$

We can represent this as shown below:

Client payment as proportion $S(t)=\frac{C D\left(t_{0}\right)+\sum_{t=t_{0}}^{T} \operatorname{rent}(t)}{\left[H\left(t_{0}\right)+M(t)\right]+\left[H(t)-H\left(t_{0}\right)\right]}$

The client's share of the house over time then becomes $X(t)$

$$
X(t)=S(t)+S(t)^{\left[H(t)-H\left(t_{0}\right)\right]}
$$

Table 2. Conventional mortgage.

\begin{tabular}{ccccc}
\hline$N$ & Monthly Payment $£$ & Interest $£$ & Principal $£$ & Balance after Payment $£$ \\
\hline 1 & 660.39 & 660.00 & 60.39 & 89,939 \\
2 & 660.39 & 599.60 & 60.79 & 89,878 \\
3 & 660.39 & 99.19 & 61.20 & 89,817 \\
$\ldots$. & & & & \\
120 & 660.39 & 527.13 & 133.16 & 78,951 \\
$\ldots$ & & & & \\
240 & 660.39 & 384.83 & 295.56 & 54,428 \\
$\ldots$ & & & & 653.09 \\
359 & 660.39 & 8.70 & 651.69 & 0.00 \\
360 & 660.39 & 7.30 & 653.09 & \\
Total & 237,740 & 147,740 & 90,000 & \\
\hline
\end{tabular}




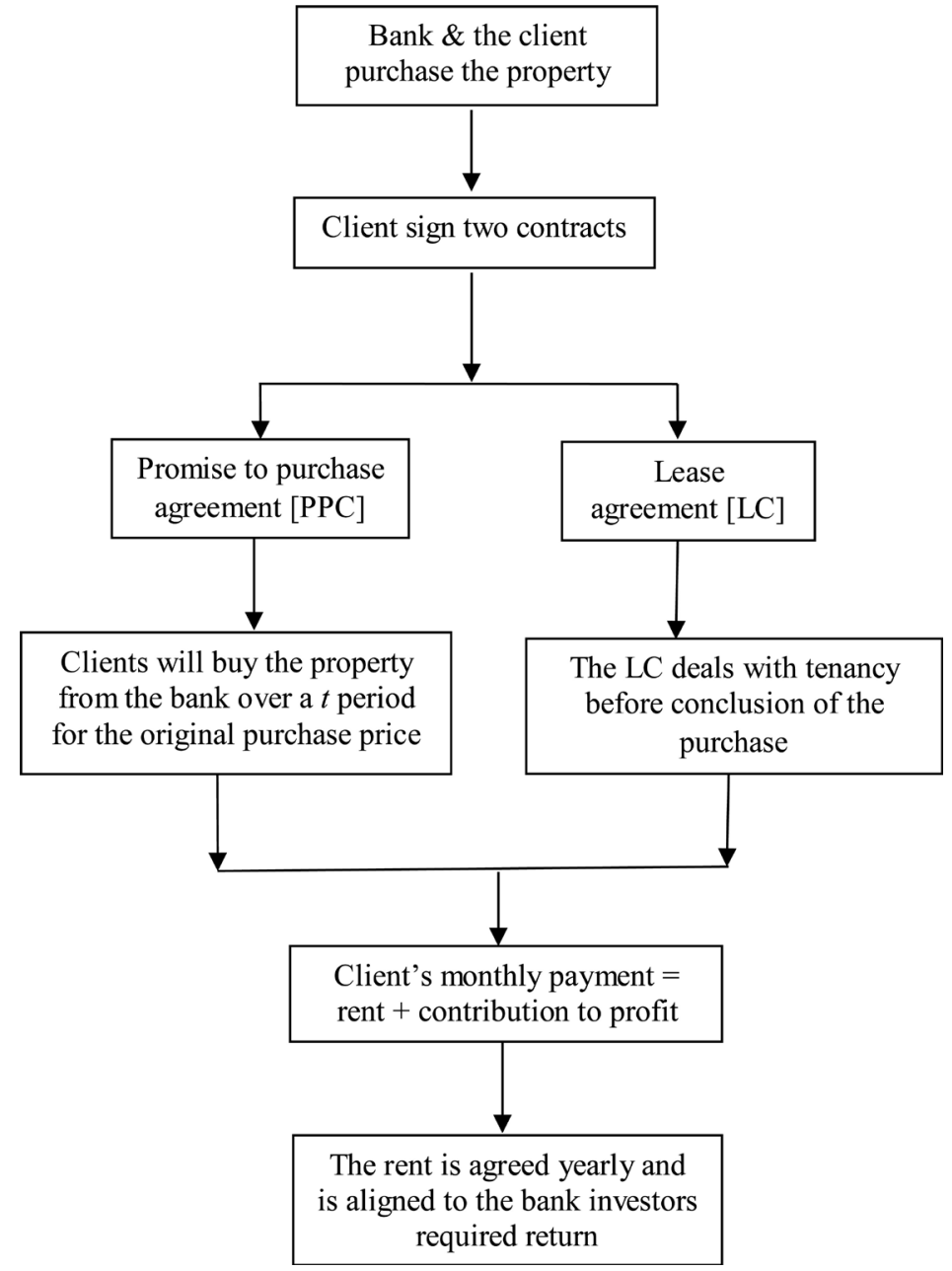

Diagram 1. Ijara based mortgage.

Here $H\left(t_{0}\right), H(t), M(t)$ and $C D\left(t_{0}\right)$ denote the initial $H\left(t_{0}\right)$ and terminal house price $H(t)$, the fee $M(t)$ and the client deposit $C D\left(t_{0}\right)$.

Clearly the Banks share at any time $t$ is

$$
1-X(t)
$$

The rent is calculated as follows:

$$
\operatorname{Rent}(t)=\text { Wage index }+2 \%=\sum_{t=t_{0}}^{T} \operatorname{Rent}(t)
$$

The risk to be shared is denoted $\left[H(t)-H\left(t_{0}\right)\right]$. The closer the client is to pay off the mortgage the bigger the risk to the client. The further the client is from paying off the mortgage and the smaller the initial deposit the bigger the risk faced by the bank.

The mark up $=M(t)$ represents bank management fees, associated costs and a margin determined by negotiation between the bank and the client. Clearly the outcome of negation about the margin depends on the relative bargaining strength of the two parties, which in turn is determined by the degree of competitiveness of the market. In so far as the Islamic mortgage market is a dis- 
tinct segment, then relative scarcity of Islamic finance favours the banks.

In the event of client being unable to meet commitments at a terminal date $t$, the client

gains/losses is $S(t)^{\left[H(t)-H\left(t_{0}\right)\right]}$ and the bank gains/losses is $1-S(t)^{\left[H(t)-H\left(t_{0}\right)\right]}$

The changes (increase) in the client shares is

$$
\Delta X(t)=\frac{\sum_{t=t_{0}}^{T} \operatorname{rent}(t)}{\left[H\left(t_{0}\right)+M\right]+\left[H(t)-H\left(t_{0}\right)\right]}
$$

In this example, the issue of riba in terms of Riba (usury) could be said to reside in the size of $M(t)$ to the extent that $M(t)$ includes a monopoly rent it can be said to be usurious.

Again if we define interest arithmetically, purely as a rate of accumulation on a given expenditure, the banks arithmetic interest, $R_{B}$ on the transaction is:

$$
R_{B}=\frac{C D(t)+\sum_{t=t_{0}}^{T} \operatorname{rent}(t)+\left[H(t)-H\left(t_{0}\right)\right]}{H\left(t_{0}\right)}
$$

Note that this is a real rate of arithmetic interest since the initial house price appears on the denominator as well as the numerator.

We now continue our discussion of mortgages since they throw light upon the nature of a significant and growing sector of the Islamic equity-based market. Let's assume an Ijara mortgage of $£ 100 \mathrm{k}$, the client (borrower) contributes $10 \%$ or $£ 10 \mathrm{k}$ and the bank contributes $£ 90 \mathrm{k}$, under this partnership both the client and the bank are thus co-owner of the property and in the case that the client chooses to rent the property he/she must pay rent to the owners. The client has an open option to increase his/her ownership in the property by purchasing the other owners (bank) shares in the property which leads to the client proportionate shares in the property increasing whilst the bank's shares in the property decrease.

Table 3 below illustrates an abridged amortization in Ijara based mortgage, assuming that the property monthly rent is equal to the conventional monthly payment of $£ 660.39$. The bank will receive $90 \%$ of the monthly rent and the client will receive $10 \%$ out of the monthly rent as co-owner which, he/she can use to increase his/her share ownership in the property, in this case, the client will fully own the property after 350 payments $(N)$, having paid a total rent of $£ 231,018$. This will lead to a saving of $£ 6000$ or $4.1 \%$ when compared to the conventional mortgage example in Table 2.

From the demonstration of the Islamic and the conventional mortgages above, we can conclude that the main difference between the two mortgages is that the former is based on sharing the equity and the risk as both the client and the bank share the ownership of the property and the conventional mortgage is based on debit and transferring/spreading the risk as the client owns all the equity and has 
Table 3. Ijara based (shared equity) mortgage.

\begin{tabular}{cccccccc}
\hline$N$ & $\begin{array}{c}\text { Payment } \\
(\mathfrak{E})\end{array}$ & $\begin{array}{c}\text { Client } \\
\text { Share }(\mathfrak{E})\end{array}$ & $\begin{array}{c}\text { Bank } \\
\text { Share }(\mathfrak{E})\end{array}$ & $\begin{array}{c}\text { Client } \\
\text { Equity }\end{array}$ & $\begin{array}{c}\text { Client } \\
\text { Equity }(\%)\end{array}$ & $\begin{array}{c}\text { Bank Equity } \\
(\mathfrak{E})\end{array}$ & $\begin{array}{c}\text { Bank Equity } \\
(\%)\end{array}$ \\
\hline 1 & 660.39 & 60.05 & 594.36 & 10,067 & 10.07 & 89,933 & 89.93 \\
2 & 660.39 & 60.48 & 593.91 & 10,132 & 10.13 & 89,867 & 89.87 \\
3 & 660.39 & 66.91 & 593.48 & 10,199 & 10.20 & 89,800 & 89.80 \\
$\ldots$ & & & & & & & \\
24 & 660.39 & 76.83 & 583.56 & 11,711 & 11.71 & 8288 & 88.29 \\
$\ldots$ & & & & & & & \\
120 & 660.39 & 144.54 & 515.85 & 22,030 & 22.03 & 77,969 & 77.97 \\
$\ldots$ & & & & & & & \\
240 & 660.39 & 318.43 & 341.96 & 48,536 & 48.54 & 51,463 & 51.46 \\
$\ldots$ & & & & & & & \\
359 & 660.39 & 652.52 & 7.87 & 99,461 & 99.46 & 538.63 & 0.54 \\
360 & 660.39 & 538.63 & 3.56 & 100,000 & 100 & 0.00 & 0.00 \\
Total & 231,018 & & & & & & \\
\hline
\end{tabular}

a secured bank loan against the value of the property and his/her assets in case of a short fall. The risk sharing distinguishes the Sharia compliance mortgage market, which is at the heart of the debate on Riba (usury).

\section{Discussion and Conclusions}

In the late 1970s and early 1980s, it was seen that conventional banking systems were intrinsically prone to instability because liabilities (short-term deposits) and assets (long-term investments) would consistently be mismatched maturity wise [17]. As the nominal values of liabilities are guaranteed, but the nominal value of assets are not, when the maturity mismatch inevitably becomes a problem banks aim for more deposits by offering higher interest rates. There is thus always the possibility that this process becomes unsustainable, confidence being eroded and the scenario of bank runs. In this system, there needs to be a last resort lendor and in place procedures for bankruptcy, restructuring and debt workout.

Earlier, in the 1950s to 1960s, [20] proposed a system where contracts are based on equity instead of debt, and where there is no guarantee of the nominal liability values as these are tied to the assets nominal values. This system was void of the instability of the conventional banking system. Later, [21] linked Metzler's model to the system of Islamic finance and demonstrated that the Islamic finance system is more stable than the conventional system as it produces a saddle point.

The root of the financial crisis was in the attempt to construct a materialist financial system that paid no regard to the issues of limitation and mortality that are the realities of human existence [22]. This system was one that had promised infinite exponential growth with unbounded consumption. If we look at Islamic 
finance, a system based on the sharing of both profit and loss, can we assume the sequence of events that culminated in such crises could have been avoided? [23] answered probably yes. Financial authorities in both the UK and USA were not forthcoming about their computation of stress tests, using the tangible common equity/tangible assets ratio, a $4 \%$ ratio that is 25 times leverage of assets. The pre-crisis levels of leverage were frequently more than twice this level. An equity-based system and profit/loss sharing of tangible assets would clearly more than meet this criterion, on reasonable assumption of the contribution of enterprise, equity being a buffer against failure Overoptimistic estimates of the enterprise value would be problematic though, and Islam does not have completely developed bankruptcy laws, so failure could diffuse and not be confined to the original investment partners. A situation could arise, such as point $f$ in Figure 1, where the entire system is bankrupt, however least on a comparative scale to that of conventional finance this is unlikely.

The underlining principles of Islamic finance are a set of ethical and morals values, therefore the debates of Islamic finance as a safer financial system in comparison with the global hyper competitive traditional finance practices introduces the ethical and moral dimension that is needed globally. [21] [24] [25] [26] points out that an Islamic financial system generates a more stable financial market. We are possibly at a turning point where change on all scales is likely to happen and new ways of being in the world could arise to fulfil our needs for both practical and spiritual compassion. We could cite a number of Quranic messages: "God does not change the condition of a people until they change their own inner selves" [11]. "Mankind was created as one nation, but they became divided because of differences among them [11]."

\section{Conflicts of Interest}

The authors declare no conflicts of interest regarding the publication of this paper.

\section{References}

[1] King, R. and Levine, R. (1993) Finance and Growth: Schumpeter Might Be Right. The Quarterly Journal of Economics, 108, 717-737. https://doi.org/10.2307/2118406

[2] Weitzman, M. (2008) The Share Economy: Conquering Stagflation and Income, Wealth, USA.

[3] Adrian, T. and Shin, H. (2008) Liquidity, Monetary Policy, and Financial Cycles. Federal Reserve Bank of New York. Current Issues in Economics and Finance, 14, 2.

[4] Goodhart, C. (2008) The Background to the 2007 Financial Crisis. International Economics and Economic Policy, 4, 331-346. https://doi.org/10.1007/s10368-007-0098-0

[5] Rarick, C. and Han, T. (2010) Islamic Finance: Panacea for the Global Financial System? Journal of Applied Business and Economics, 11, 27-32.

[6] Brunnermeier, K., Crockett, A., Avinash, P., Shin, H. and Goodhart, C. (2009) The Fundamental Principles of Financial Regulation (Geneva Reports on the World 
Economy). International Center for Monetary and Banking Studies, Geneva, 11. https://www.princeton.edu/ markus/research/papers/Geneva11.pdf

[7] Warde, I. (2011) Islamic Finance and the Global Meltdown, Business Islamica Magazine. UAE, Dubai.

[8] Reder, W. (1999) Economics. University of Chicago Press, Chicago.

[9] Stigler, G. (1966) Theory of Price. 3rd Edition, Macmillan Library Reference, New York.

[10] Friedman, M. (2009) Price Theory. Eigal Meirovich, London.

[11] Quran.

[12] Friedman, M. and Schwartz, A. (1963) Monetary History of the United States, 1867-1960. Princeton University Press, Princeton.

[13] Mandelbrot, B. and Hudson, R. (2008) The (Mis) Behaviour of Markets: A Fractal View of Risk, Ruin and Reward. Profile Books, London.

[14] Taleb, N. (2007) The Black Swan: The Impact of the Highly Improbable. Random House, New York.

[15] Wolf, M. (2010) Fixing Global Finance. Yale University Press, New Haven.

[16] Minsky, H. (2008) Stabilizing an Unstable Economy. McGraw-Hill Professional, New York.

[17] Minsky, H. (1982) Can "It" Happen Again? Essays on Instability and Finance. M.E. Sharpe, Armonk.

[18] Minsky, H. (2008b) John Maynard Keynes. McGraw-Hill Professional, New York.

[19] Reinhart, C. and Rogoff, K. (2009) This Time Is Different: Eight Centuries of Financial Folly. Princeton University Press, Princeton. https://doi.org/10.2307/j.ctvcm4gqx

[20] Metzler, A. (1950) Grahams Theory of International Values. American Economic Review, 40, 301-322. https://doi.org/10.1016/0002-8703(50)90177-3

[21] Khan, M. (1986) Islamic Interest-Free Banking: A Theoretician Analysis. Staff Papers of the IMF, 33, 1-27.

[22] Boeri, T. and Guiso, L. (2008) The Sub-Prime Crisis: Greenspan's Legacy. In: Felton, A. and Reinhart, C., Eds., The First Global Financial Crisis of the 21 st Century, CEPR Policy Portal, London.

http://www.voxeu.org/index.php?q=node/1352

[23] Tran, N., Chen, H. and Joslin, S. (2012) Rare Disasters and Risk Sharing with Heterogeneous Beliefs. The Review of Financial Studies, 25, 2189-2224.

https://doi.org/10.1093/rfs/hhs064

https://academic.oup.com/rfs/article-abstract/25/7/2189/1601202

[24] Siddiqi, M. (2009) Current Financial Crisis and Islamic Economics. Insights, 1, 141-150.

http://ierc.sbu.ac.ir/file/article/current $\% 20$ financial\%20crisis $\% 20$ and $\% 20$ islamic $\% 2$ 0economics 93000.pdf

[25] Chapra, U. (2011) Global Islamic Financial Crisis, Can Islamic Finance Help? In: Langton, J., Trullols, C. and Turkistani, A.Q., Eds., Islamic Economics and Finance, IE Business Publishing, Palgrave Macmillan, London, 135-142. https://econpapers.repec.org/bookchap/abdieibch/32.htm

[26] Bagsiraj, M. (2009) Financial and Economic Crisis an Alternative Indian Approach. Radiance Views Weekly, 46, 1-4. 